\title{
THE TOPOLOGICAL RELATIONS OF CORNER BUILDINGS AT STREET JUNCTIONS
}

\author{
Richard HERRIOTT \\ Design School Kolding, Ågaden 10, Kolding 6000, Denmark \\ E-mail: rhe@dskd.dk
}

Received 30 May 2016; 4 October 2016

\begin{abstract}
As in furniture and product design, the handling of features such as junctions of street facades is a matter worthy of consideration. The article considers the role of the corner and corner buildings in the architectural relations of the street. It examines the role of corners in the urban structure and the reasons why they are no longer much used. A typology of corner building arrangements is proposed. Referring to affordance, legibility and Weber's (1995) psychological approach to perceived architectural space, the paper discusses the value of clearly articulated corner constructions using selected examples.

The dominant modes of building in the post-WWII period tend towards two extremes: high rise/high density and low rise/low density, both often characterised by disconnected building masses. Both modes reject the well-developed formats generally used up to the 1920s. These relied on moderate density, moderate height and conjoined buildings to create clearly defined, legible streets characteristic of an integrated urban fabric. This paper argues that certain morphologies make for better corner designs leading to more understandable street layouts. It also argues that quantitative recommendations in planning guidance are insufficient to ensure desirable outcomes in street design.
\end{abstract}

Keywords: urban planning, corner design, building typology, Modernism, morphology, affordance.

\section{Introduction}

In the song "New Killer Star" (Bowie 2003) there is a cryptic line: "all the corners of the buildings, who but we remember these, the sidewalks and trees?". The corners of buildings are neglected, and so too are the way buildings join to buildings in urban areas. The lyric draws attention to an ambiguity concerning something both forgotten and important - for why else refer to it? The aim of this article is to examine the topology and geometry of street corner design and the corner's role in the urban fabric, and redress the ne- glect of street-to-street edges. It will be argued 1) that the corner provides the joint where facades meet at junctions and 2) that corners ensure an advantageous arrangement of facades and so conceal the potentially unattractive elements such as gables and rear walls (see Fig. 1, centre and right images).

The methodology used is to review a selection of literature on urban typologies; to present examples of corners and street designs from Northern Europe, the United Kingdom and Ireland; to discuss the role of the street in the urban fabric and examine its relation to

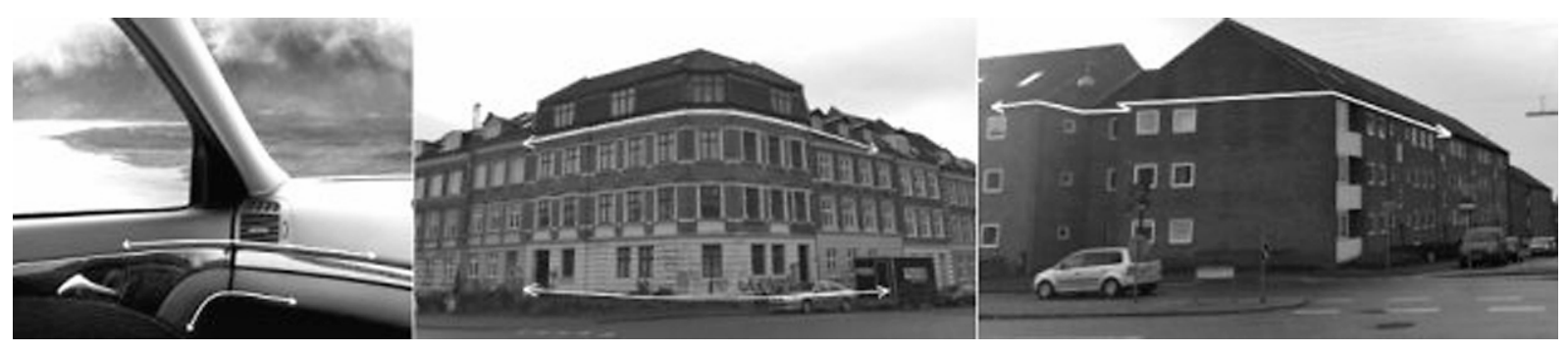

Fig. 1. The aesthetic ideals of the vernacular street corner (middle) have more in common with a modern vehicle interior (left) than do the mid-20 ${ }^{\text {th }}$ century design (right). Notice the flow of surfaces in the centre and left image. The corner buildings on the right don't flow. 
change in planning ideals characterised by the Congrès International d'Architecture Moderne (CIAM), before presenting a typology of corner junctions.

The ideas presented are informed by an experience of industrial design which places considerable emphasis on solutions for conjoined parts, overall coherence and detail craftsmanship (See Fig. 1, left image). The relation is metaphorical in that whilst industrial products are assembled in a single process, a street assembly may take many years to reach completion. So, when discussing the "assembly" of a street's elements one is talking as if the street is the result of single process. The similarities are that there is a joining of separate entities into a newly connected whole and this conjunction may feature formal articulation (decoration, expression). The differences relate to the time scale of the process, the scale of the objects and the materials. What the author wishes is for the reader to consider the resultant masses of a streets block as if assembled as a whole (For this, compare the three images in Fig. 1). In some cases they are and in some cases the buildings are not the result of simultaneous construction processes.

This paper draws on the work of Kevin Lynch and Rob Krier $(1979,1994)$ on the basis that way-finding, sense of place and arguments concerning urban form are of perennial importance. Although their work is not new it is still of continued relevance. The issues they discuss remain problematic. The study draws on Lynch's (1960) concepts of legibility and Weber's (1995) psychological approach to the perception of space. The article concludes with a discussion of how the corner typology might be renewed in line with contemporary goals for densification and sustainability.

In order to retain the focus of the article on corner morphology, the author has decided to resist the temptation to deal with the many social, political and economic forces that shape cities. To begin dealing meaningfully with these factors would require more space than it possible to devote to these nonetheless important points.

The principle research questions are: what is the common morphology and typology of street corner design? How have changes in urban planning changed the expression of corners over time? What role do the corners have in the urban fabric?

\section{Theoretical and conceptual framework}

Scruton (1994) defends traditional urban design from a conservative viewpoint, placing emphasis on the private; this paper is written from a position from the left of the political spectrum. That view emphasises the public and the civil. While Scruton (1994) sees the failures of planning as an endorsement of Hayek's
(1974) critique of socialism this paper is anchored in a view that the failures of planning are due to 1) flawed models inspired by worthy social goals in the period up the mid-1970s and thereafter 2) excessive deference to market-based mechanisms and an overreliance on quantitative factors (setbacks, traffic, parking requirements, for example) as determinants.

Concerning terminology, a corner is defined for this article as where one or more buildings are arranged at the junction of two thoroughfares. Depending on the context, this loose definition includes the relationship between facades or the relation between buildings at junctions. Further, this paper refers to classical or vernacular versus modern street design. This term "classical" (not "Classical") is a working shorthand for pre-CIAM approaches to urban planning and not a reference to the architecture of antiquity or subsequent revivals of that style. The term "modern" (not "Modern") is here used as shorthand for post-CIAM approaches and, more generally, contemporary architecture and planning. For practical purposes these terms conflate a temporal definition and to some extent a stylistic definition. Of course, some contemporary designers refer back to pre-modern approaches and, before CIAM, some designers were already using alternative approaches to planning rather than those which predominated up to 1933 and the period immediately thereafter. It is also noted that in some regions the turn away from the dense urban form occurred earlier, such as the British suburbs of the 1860s.

The conceptual framework draws on Lynch's (1960) concepts of legibility and Weber's (1995) psychological approach to aesthetics which has three pillars: that one can perceive (1) intrinsic value, (2) order and wholeness and (3) a hierarchical structure. I will also make use of the concept of affordance, more commonly used in relation to industrial design. It is relevant here as a means to discuss how the form of a street suggests what is possible for the viewer to do. Norman (2002:9) discusses affordance in relation to objects: "An affordance is a relationship between the properties of an object and the capabilities of the agent that determine just how the object could possibly be used". These three theories together explain (1) how one understands one's place in space, (2) whether or not the space is aesthetically satisfactory and (3) how one can move in the space. Referring to Figure 2, one can read the landmarks of the street (rather clearer in the left picture), judge if the appearance is satisfactory and understand without ambiguity which direction one can move.

Acknowledging Vollmer's (1993) discussion on the demarcation of science, this work does not allow for reproducibility or predictability. It does however meet 


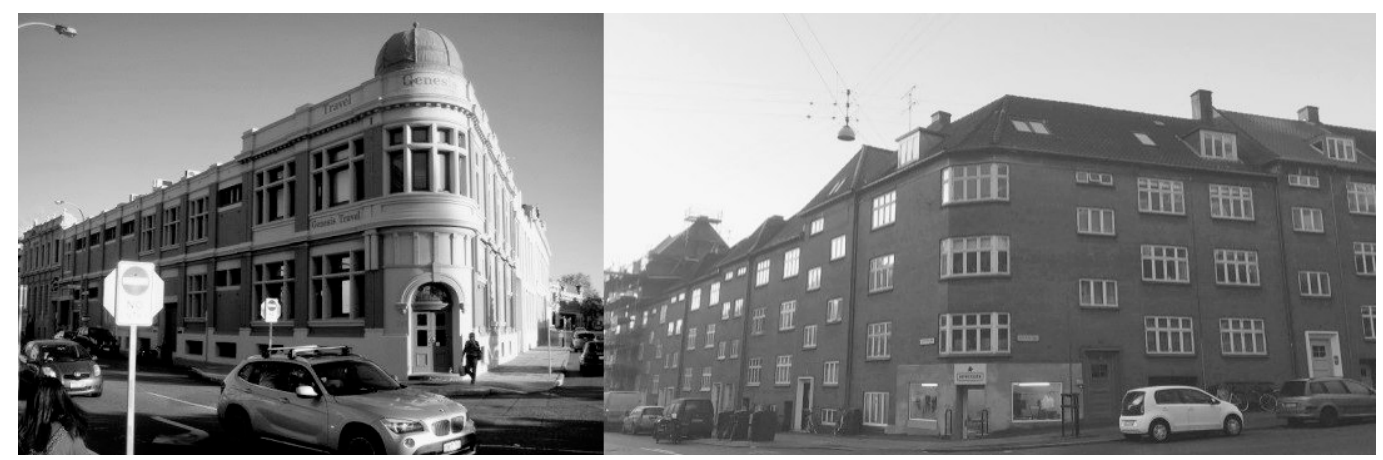

Fig 2. Two corners buildings, with and without decorative elements

the requirements of fecundity and simplicity in that considering the architecture of corners one can understand the key aspect of classical town architecture and the consequences of the novel approaches applied in the 20th century. The concept is also simple in that it posits that the corner building has an essential role in unifying the urban fabric and ordering the internal and external topologies of the "urban theatre".

\section{Methodology}

The methodology deployed in this study is essentially empirical. The data consist of examples drawn from the built environment and a selection of the diverse literature discussing architecture and urban planning. I have not attempted a quantitative analysis. There seems no unambiguous or non-contentious means to define and separate signal from noise (examples and non-examples), to borrow from Shannon (1949). A quantitative analysis also would not address the qualitative aspects this paper focuses on. At issue is how corners are formed and not their spatial distribution or their number in urban areas.

The buildings and urban areas which have informed the underlying assumptions of this article are from Germany, Denmark, Switzerland and the United Kingdom and Ireland. I do not address the urban realms of Southern Europe which has different urban traditions related to light and the reduced prevalence of front gardens. The photographs show Danish and Irish buildings primarily, selected as exemplars of typical forms. As such this work is closer to historical research and the humanities than science but it still presents observations and interpretations that can be examined and contested.

Regarding delimitation, in this article I will not address corner building found on squares or plazas. This class of corner in the urban fabric has a different set of requirements, being an inwardly-orientated corner surrounding an area of congregation and not transit.
The data set (the built environment) is large and in this study has been treated as a collection of more and less relevant examples from which to choose. By "built environment" I am referring to urbanised areas ranging from long-established city centres through to suburbanised areas of recent construction. The literature selection drew from the library of the Aarhus School of Architecture and the State and University Library, Aarhus, Denmark. The State and University Library is a copyright library with full access to all major periodicals either in hard copy or e-format. Google Scholar provided supplementary material. The specific search terms "corners" and "the corner problem" produced much non-relevant material concerning a detail of Classical (ancient Greek) architecture. The search method settled on the use of "street" and "urban planning" to create a large list of potential target sources. Further searching required inspection of the resultant sources via the abstracts or tables of contents and indices. The literature selected here satisfied the requirement of referring to street design where it has a bearing on corner architecture, either by inference or direct reference.

\section{Literature review}

The literature on street corner design is sparse despite a wealth of publications on urban planning and urban space generally. The following volumes constitute an important set of references in the study of urban space but direct insights on the corner per se are notably absent.

The Image of the City (Lynch 1960) considers the importance of paths, edges and landmarks. The corner is not singled out for analysis of its role in unifying urban space but the role of paths is. Lynch does note that "junction nodes occur automatically at major intersections, and by their form should reinforce those critical moments in a journey" (Lynch 1960: 84). It is not clear whether Lynch is thinking more of the space made by the thoroughfare or the buildings surrounding it. 
In Urban Space, Krier (1979: 15-62) proposes some outlines of typologies of squares and streets and the effect of building sections and elevations. The corner building is not addressed though Krier does hint at the existence of corners in a diagram, reproduced below (Fig. 5). Lynch (1984) and Rossi (1984) do not make detailed reference to streets or street junctions. Moughtin et al. (1992) concede "little analysis" of the form of streets has been conducted but go no further with the matter. Moughtin et al. (1995) devote a chapter to the decorative aspects of corners.

Madanipour (1996) offers some insight on the relationship of urban space to the architecture of individual buildings. The book only notes the role of streets as one of the main elements in the streetscape. While Cuthbert's (2003) Designing Cities neglects street corners and street design, Southworth and Ben-Joseph (1997) address street width, scale and geometry in terms of evolving design standards, a means for social control and traffic accommodation but not the relation of buildings to the streets or junction design.

Streets and Patterns (Marshall 2005) "takes up the challenge of how to create better urban spaces without compromising the basic functionality of circulation and access". The words "corner" and "corner building" are absent from the text. The Art of City Making (Landry 2006: 5) also omits to mention relevant terms but again talks about the value of streets. In Urban Design Futures Geuze (2006) discusses the role of the street and why they are seldom used in new urban areas. Building Types and Forms (Steadman 2014) exhaustively runs through possible built forms for different types of urban block and sites (e.g. p. 247). Steadman provides an analysis of building depth, daylighting requirements and the consequences of the site layout on floor plan but the corner building is not addressed. This is despite corner buildings having distinct characteristics related to internal construction.

Of the literature reviewed, Moughtin et al. (1995) and Holsten (1999) make the greatest contribution. Moughtin et al.(1995: 51) write that the corner "when given emphasis with decorative treatment becomes memorable in the mind of viewer. It then takes on added significance, performing the role of landmark". This adds detail to Lynch's concept of landmarks. Holsten (1999: 251) discusses the social significance of the corner. Brasilia, which is one of the most clearly articulated visions of the CIAM model of modern city, is bereft of street corners: "The discovery that Brasilia is a city without corners produces a profound disorientation".
The main finding here is that the entire bibliography of this article, one devoted to urban design in its various forms, is almost bereft of references to the corner as an element of the urban landscape. A similar point may be made about industrial design literature and its discussion of assembly concepts. Much of the art of industrial design deals with junctions and joins: how things are put together: “...for those qualities of appearance which hitherto have been universally required are the qualities of workmanship: a good surface, a neat fit, a clean job..." (Pye 1978: 71). But these problems are implicit, hidden inside ideas of craftsmanship and aesthetics in the abstract.

\section{Towards a typology of street corners}

In order to put a proposed typology of street corners into context, this section explores two related aspects. Firstly, there is a discussion on ways to conceive of the street as a space. Secondly, the paper describes changes in the way buildings and roadways relate to each other in terms of the Gestalt concept of the figure-ground pairing. As the urban structure gets less dense, buildings form figures on a ground that is hard to perceive. Taken as a given is the concept of façade hierarchy such that some visible walls have a higher importance than others. In short, the entrance façade generally has higher importance than the rear or gable walls. The terms can be fluid such that in modern constructions the entire building may have no clear gable or rear. In classical urban settings, gable walls are often party walls leaving only the entrance façade and rear visible (see Fig. 3). In post-war urban settings the gable wall becomes visible (see Fig. 4).

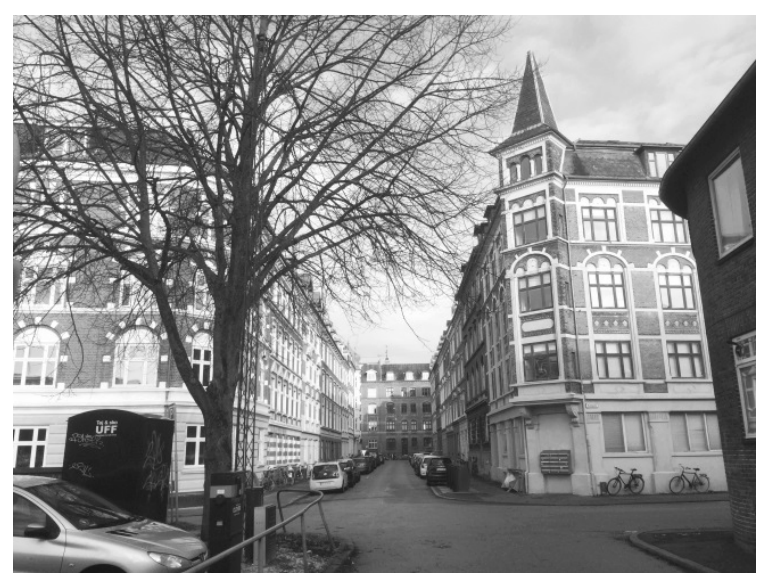

Fig. 3. Classical street blocks, Aarhus, Denmark. The corners demarcate the paths forward, left and right 

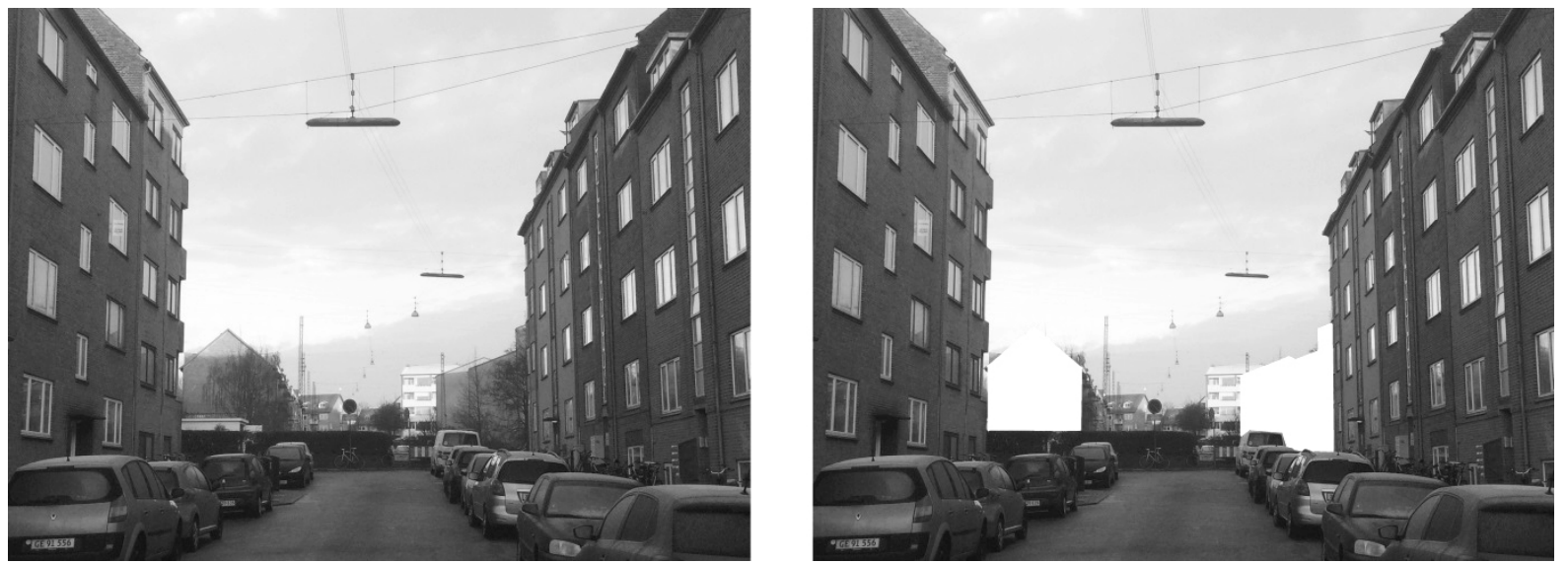

Fig. 4. The classical street discontinued. Post-war development is visible in the background as exposed gable walls (highlighted in the image, right). The windowless gable walls do not suggest habitation

\section{Understanding the street}

The debate on urban density is a long one and quite inconclusive. The definitions of desirable density are contested. There is insufficient space here to recapitulate the main points of the topic or to attempt a firm definitions other than to refer to examples: the preCAIM city centres are examples of higher density; carbased suburbia is typically low density. Confounding this very rough distinction is the fact that Modern architects found ways to attain high densities per site while avoiding other attributes of the classical city centre (see Fig. 8 below). For this section the focus is on the street corner, the folded street façade and its geometrical articulation, as the anchoring element of an urban landscape.

How are the street and block to be perceived? Is the street a bounding space or is the space carved from a mass of brick and concrete? Weber (1995: 137) defines the two main ways in which the relation of buildings and space can be understood, as buildings set in a space or as spaces bounded by building surfaces:

"...At one extreme in this relation is the architectural solitaire: the isolated structure that dominates the surrounding space $[\ldots]$ at the other extreme are regularly shaped urban spaces, such as the Neoclassical boulevards of Paris, with their similarly articulated founding facades. Most often, however, buildings and the spaces between them compete for dominance, as the spatial boundaries present visual centres which draw attention away from the primary spatial figure".

Trancik writes (1986: 8) "in the compact, evolved form of traditional European cities, streets and squares are carved out of the dense mass of buildings". Holsten
(1999: 252) and Moughtin et al. (1992: 133) also use this metaphor. This paper opts for the view of the street as a space defined by the surfaces of building masses since the buildings dominate the space. Arnheim (1977: 76) formulates this as the street as a figure: "the walls are experienced as the sides of urban canyons [...] his eyes direct his course through an open channel". Krier (1979) shows the "canyons" of the classical city versus the disjointed facades of suburbia (Fig. 5 top left, bottom left).

While description of streets as if carved out from large blocks is visually accurate, it is functionally misleading. Buildings are aligned around thoroughfares, roads and lanes, a process of addition not subtraction. Market squares and, later, formal parks were defined and buildings were arranged around them. One can say streets look as if they are carved out of blocks of solid
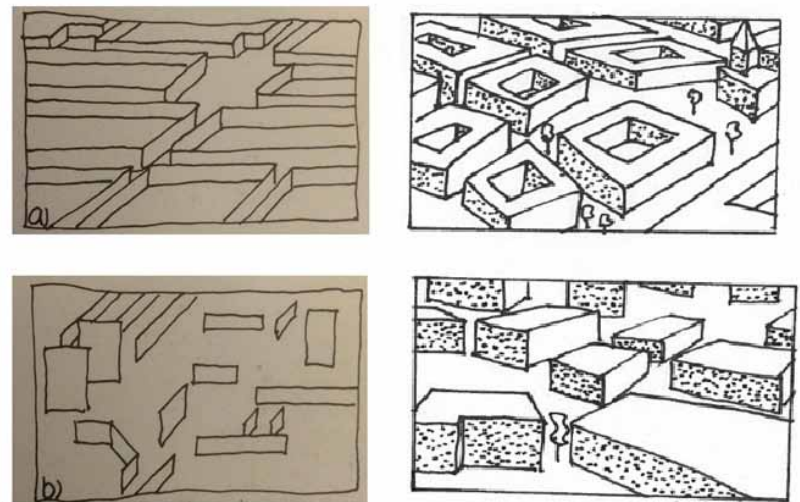

Fig. 5. Diagrams on the left by Rob Krier (1979) and interpreted (right) by the author. The top diagrams show the urban space of street block and corners. Lower, the landscape of free-standing structures. The pairing develops a point made by Krier (1979: 81) about how in the modern city the street/ building relationship is weak. Whilst Krier's diagram isolates the facades, the author shows schematic blocks or buildings 


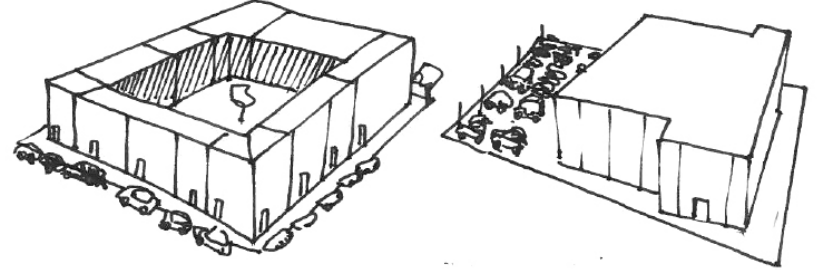

Fig. 6. The street block (left) compared to the free standing large building (right). The street block's functional, less decorative, surfaces are effectively concealed and the facing streets all have a public aspect. For the free standing block only one facade has a public access. The others may be decorated to look as if they do, often they do not

material. I would prefer to say what they are and rather than what they seem to be. They are volumes massed together and aligned to thoroughfares.

The CIAM movement desired to "free" buildings from the street (Neal 2003: 4; Holsten 1999: 245). The emphasis on private cars led to demolition, street realignment and the building of boulevards in place of smaller carriageways. In some cases, corners were a specific obstacle to traffic flow and were removed to increase cornering speeds, exposing the rear and gable walls of the remaining buildings.

The last and contemporary phase of urban planning, coincident with the second, is to avoid party walls, to allocate large spaces to parking and to align the buildings in ways discordant with existing building lines, primarily to optimise lighting and to achieve rectilinear building plans (See Fig. 6). Ford (2000: 8) notes that most of the modern urban landscape consists of "free floating" buildings and it makes little sense to talk about the space between buildings but buildings in space. Marshall (2005: 221) describes this as "point blocks or development pods appended off a skeletal network of distributor roads". The street corner is thus reduced to being that place where the road changes direction. The road's path is usually separated in space from the nearest building's corner. It is as if the walls of a maze and the path through it become detached from each other (see Fig. 7).

That streets have much to do with the quality of the settlement (Lynch 1984: 429) is something of an understatement. In this paper this is taken as a valid assumption rather than a point to argue at length. A counterpoint to this is the work of Gans (1968) who accuses both modernists and defenders of the street (such as Jacobs 1993) as demonstrating the same fallacy, the planning fallacy: "it leads [Jacobs] to ignore the social, cultural and economic factors that contribute to vitality or dullness" (cited in Moughtin et al. 1992: 131).

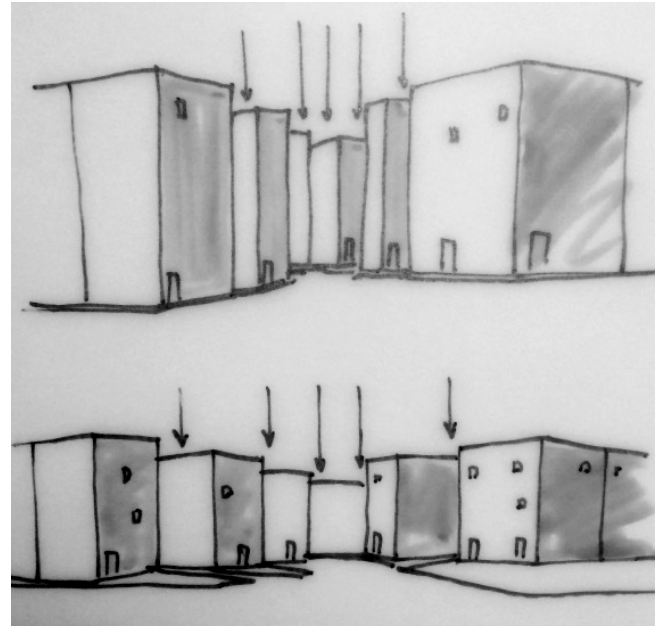

Fig. 7. The top drawing shows blocks with the facades in contact with the footpath edge. The lower drawing shows building set back from the footpath. The arrows indicate possible avenues. In the lower drawing the avenues are less clearly perceived

While it is true to say that the attractiveness of integrated urban areas is partly a function of their central location, it is not the whole explanation. People value these places also because of the way they look and the amenities offered. The aesthetic and amenity appeal of these areas is largely dependent on their structure. It is the legibility (Lynch 1960:3) of the street fabric that allows the rest of the forms to make sense. The close fit of buildings to the paths informs the viewer of how to move through the area.

The problems with the disjointed and fragmentary landscapes of car parks, verges and free-standing buildings have been observed by some practising architects themselves. The debate is too complex and well-developed to be discussed in detail. One or two examples must suffice. For example, architects Willie Miller Urban Design (2014) write: "the shape-making and form-giving that once passed for urban design or the underwhelming architectural master plans for the property development industry wrapped up in elemental philosophy about space, sunlight and openness just don't cut it anymore". New Urbanists such as Leon Krier (1994) have focused on the problems of large-scale, free-standing buildings as much as on the matter of style. For many critics the problem with Leon Krier's intervention in the New Urbanist debate is that he has a preference for the use of Classical and vernacular forms. This has distracted very largely from his point that the subjective appeal and the legibility of the street require not only certain scales of building but that they be related to one another in a quite defined way. 


\section{Tradition interrupted}

The previous section dealt with how streets and urban spaces appear. This section deals with why they look the way they do. The custom of organic and locallyevolved design solutions has been interrupted since the CIAM conception of planned cities was implemented (Moughtin et al. 1992: 129; Mumford 2009: 3). Park Hill, Sheffield (1945) is by no means atypical (Fig. 8). That conception was based on the functional organisation of regions, cities and neighbourhood units (Mumford 2009: 25). The roots of this attitude are in a positivist view of architecture ("Taylorism") that assumed such an approach would result in better buildings and cities. Le Corbusier asked for "standardization, industrialisation and Taylorization" (cited in Mumford 2009: 3) ${ }^{1}$. The destruction of city centres during the Second World War offered an opportunity to test ideas of new urban form on the newly cleared plots. Düwel and Gutschow (2013) writes that "In the early $20^{\text {th }}$ century, multi-storey residential buildings and corridor street frontages were rejected absolutely, for reasons that went far beyond hygiene and sanitation concerns". For an example of the disdain in which the street was held, the Architect and Building News (1941, cited in Düwel, Gutschow 2013: 293) showed a photograph of Coventry's medieval core over the caption "This must not happen again”. Düwel and Gutschow (2013) cite the politician and entrepreneur Alfred Hugenberg who wrote in Die Neue Stadt (1935) of Berlin streets: "The endless accumulation of tenements, all similar in form, looks monotonous and depressing. There is no trace of artistic thought" (See Fig. 9). As late as 1973 writers such as Bruno Zevi (1978) recommended concepts such as the Plug-In City by Archigram which was a "forest of skyscrapers

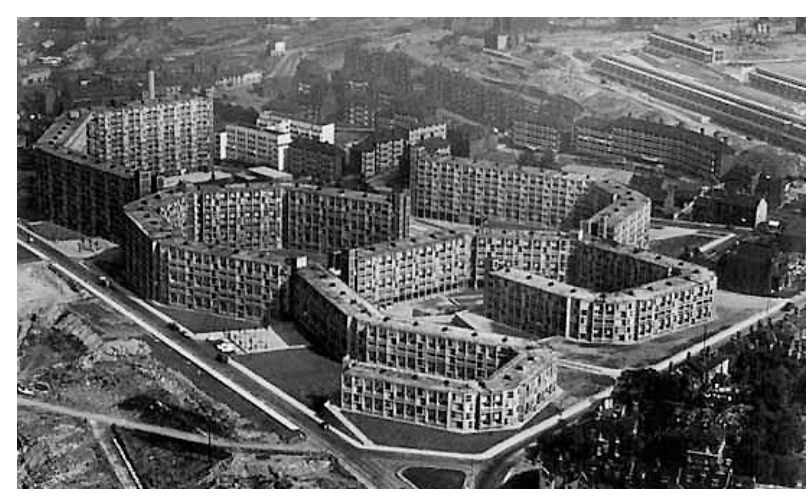

Fig. 8. Park Hill in Sheffield (1957-1961): influenced by modernist principles of urban planning. Note the few corners, the disconnection of the building from the road

\footnotetext{
1 Industrial design has spent the best part of three decades trying to get away from the ill-effects of standardisation. First, via ergonomics, then design-methods thinking and finally user-centred design integrating psychological elements with physical factors.
}

connected at various levels". Underlying Zevi's recommendation is that the list of functions (Zevi 1978: 7) determined architecture which "leads to a rejection of all traditional norms and canons". Zevi does not consider that the list is written by the architect who is free to choose what might be on that list (see also: Michl 1995).

Separation of functions, accommodation of motor traffic and a focus on buildings not streets as the unit of development has resulted in a disintegration of the urban fabric (Moughtin et al. 1995). Considerations of light in-fall have also over-ridden other considerations in alignment. Consider the aerial photo in Figure 10 (below). The north-south buildings of suburban Aarhus, Denmark, have been marked out. About six or seven substantial east-west blocks are present compared to about forty five north-south blocks. This design solution reduces living opportunities for those who might have traded off reduced daylight for proximity to the urban centre. At street level, one does not perceive the ordering apparent from the plan view.

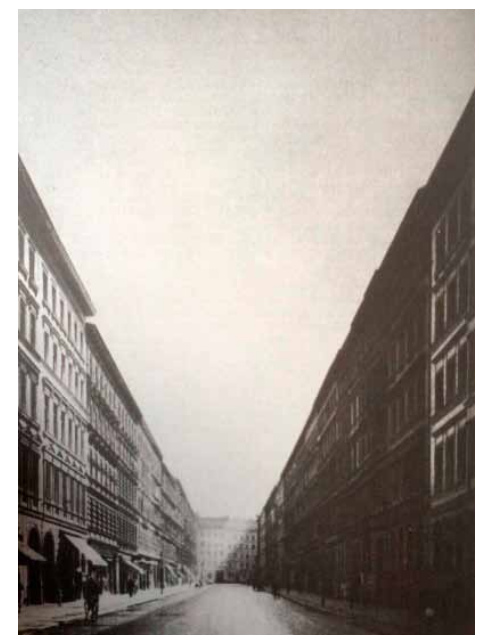

Fig. 9. Image from Hugenberg's Die Neue Stadt. "...no trace of artistic thought", wrote Hugenberg (cited in Düwel, Gutschow 2013).

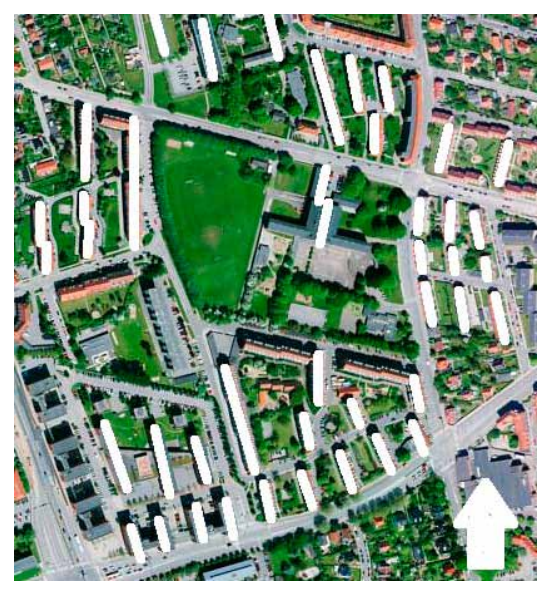

Fig. 10. No conjoined corner buildings - an aerial photo of suburban Aarhus, Denmark. The arrow points north 
Scharoun's 1954-1961 Charlotttenburg-Nord project (Syring, Kirschemann 2004) achieves the same effect with a disconnection of building masses and main roads. There are no corner buildings.

\section{Types of corner}

This section is concerned more with the topological relation of buildings to each other where they are situated at street junctions. It is less concerned with the formal articulation the resultant building or buildings. For example, whether one or two buildings meet at the corner is of greater importance to this study than how the resultant geometry is articulated, whether if it is castellated or a right angle (see Fig. 2), for example. For this reason the buildings in Figure 11 (below) are shown diagrammatically.

"Corners and walls are mutually dependent on each other for the definition of a space....it is corners which tell us where we are" (Thiis-Evensen 1987: 121). Moughtin et al. (1995: 49) discuss the corner in terms of decoration: "the design of the corner where two planes meet is a visual problem giving scope for expression in the design of almost any artefact, the design of the urban scene is no exception to this rule. Indeed the handling of the corner is often an indication of the quality and mastery of the designer". Moughtin et al's (1995: 49) typology is based on geometry under three categories: angular, curved and towered corners. This study finds this classification incomplete and proposes a larger set of types (discussed below, see also Fig. 16). Following from this notion a system is proposed, one based on the number of buildings at the corner and the relation of the facade, gable walls and rear of the structure (discussed below, see Fig. 11). For pre-modern buildings these three categories are sufficiently well understood terms not to require further elucidation. In modern buildings the categories are perhaps harder to judge since free-standing blocks, for example, may have outer walls that are all treated as a main facade or may be arranged such that the functional front and functional rear wall may be continuous. Another division in Modern architecture might be that between fluid corners as exemplified by the School of Amsterdam and designs that break up the main volumes in attempts to articulate functional elements (neoplasticism). Erich Mendelsohn's work (Stephan 1988) e.g. the 1928 Petersdorff department store Breslau, and 1928 Schocken department store, forms an interesting intermediary exploiting the potential of curved glass and cast concrete to give decorative expression to the corner through the dominant mass of that element. The corner is not a secondary mass but either equal or primary with respect to the adjoining masses. However, underlying this one can fit Mendelsohn's examples into category 2 (below, Fig. 11).

From this typology one can understand the relationship of the three types of wall to the rest of the street. Semantically, the facade is the face of the building. The other surfaces lack this communicative relation to the public space. In descriptive terms, the building has one main surface that will "address" the public area. The gable and the rear wall do not have this capacity except in unusual circumstances. Those designs that expose a gable wall (without windows) to
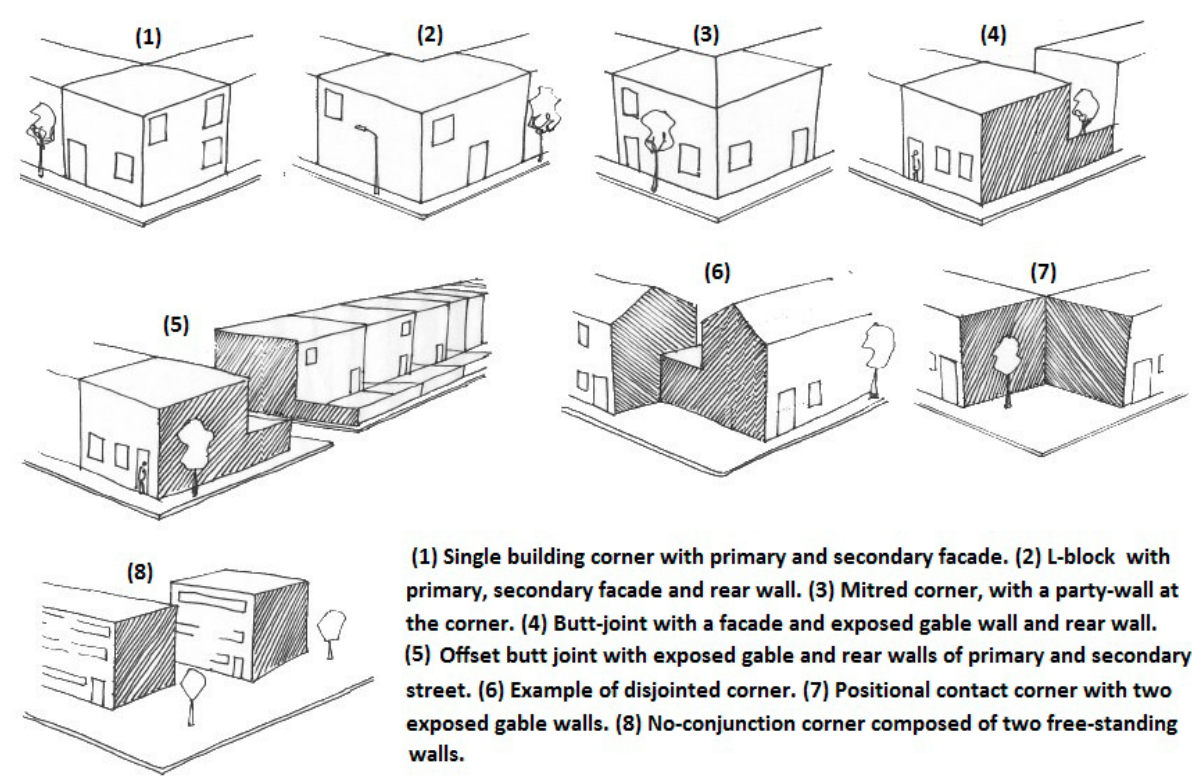

(1) Single building corner with primary and secondary facade. (2) L-block with primary, secondary facade and rear wall. (3) Mitred corner, with a party-wall at the corner. (4) Butt-joint with a facade and exposed gable wall and rear wall. (5) Offset butt joint with exposed gable and rear walls of primary and secondary street. (6) Example of disjointed corner. (7) Positional contact corner with two exposed gable walls. (8) No-conjunction corner composed of two free-standing walls.

Fig. 11. Typologies of street corner 
view are signalling that one of the streets is of lesser importance. Some buildings turn their backs to the streets such that the surface facing the street is functionally a rear wall (See Fig. 12).

Some of the design solutions outlined above are attempts to address problems inherent in the closed corner (see Figs. 12 and 13, for example). These include ownership of the backyard, interior illumination, building alignment, the cost of constructing with nonright angles (a problem for the mitred corner) and fire regulations. The use of the offset butt joint (Fig. 11, number 5) gives British and Anglo-Irish suburbs of the Georgian and Victorian period their peculiar fragmentary quality, with their long stretches of gable and garden walls and direct views of the rear walls of houses.

Some of the solutions are dependent on certain land-ownership traditions. The L-plan monoblock (Fig. 11, number 2) can be made to work well in dense urban areas with ownership divided vertically, into apartments. In Scandinavia, the custom of social co-operation allows residents to share a single back yard. Infill developments in the 70s and 80 s varied the concept by placing the entrance off the street so the wall facing the street lacked doorways (see Fig. 12). The dispersed, unstructured and exposed character of Scandinavian

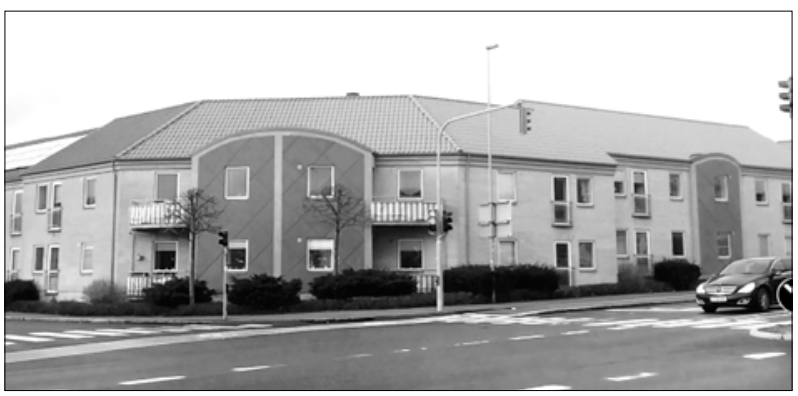

Fig. 12. Late $20^{\text {th }}$ century corner from Silkeborg, Denmark. Note the absence of a pedestrian entrance. These entrances are on the opposite side of the building, associated with offstreet car parking (see Ford 2000: 8)

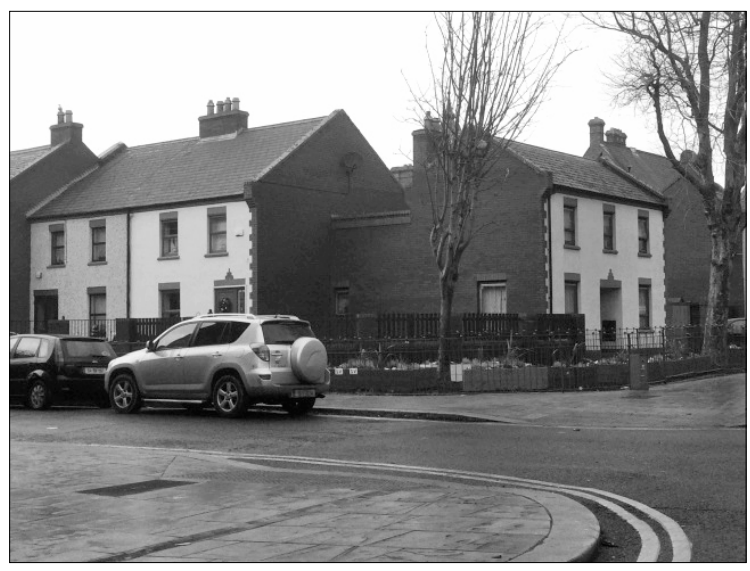

Fig. 13. Disjointed corner. Dublin, Ireland suburbs derives in part from the absence of clearly articulated corners.

The offset butt joint avoids placing a building on a corner with a non-standard garden (which might be too large) at the front and avoids dividing up the expected rear garden in a non-standard way. The consequence of the offset butt joint is to create an exposed gable wall and long garden wall facing onto the secondary street. The first building to face the secondary street is set back from the line of the main thoroughfare by the total length of its garden plus the length of the site on the primary street (see Fig. 11, number 5). This diminishes the clarity of the start of the subordinate street. A similar problem, though to a lesser degree, attends to the butt joint (Fig. 11, number 4, and Fig. 14). For the disjointed corner the precise relationship of the road junctions and buildings is illegible at ground level (Fig. 11, number 8).

From these examples, it is apparent that the geometry of the junction defines the space where the streets intersect and the affects the clarity of the affordance of the area. Since the perceived openness of the junction increases rapidly as the radius of the junction increases, small differences in the way the corner is treated have a large effect. Bevelling or rounding the building

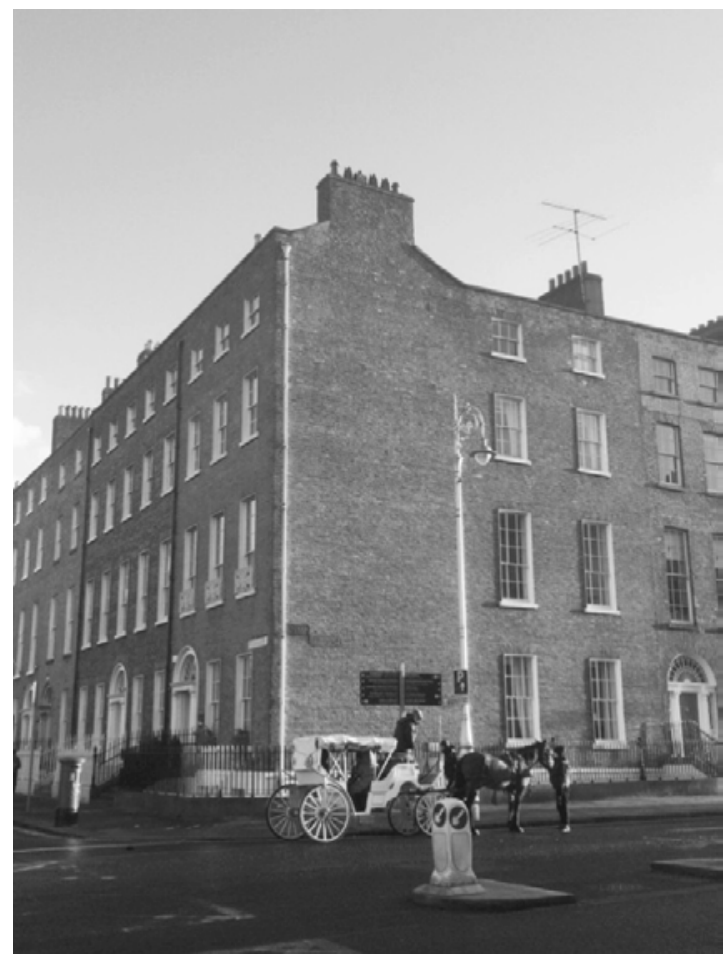

Fig. 14. Butt-joint corner, though with an additional flourish. The side facing the camera is half gable wall, and half a secondary facade (lacking a doorway, which is on the primary façade, left). The architect missed an opportunity for a corner building that suited this site's views over the Duke of Leinster's Dublin mansion (now the seat of national government in Ireland) 


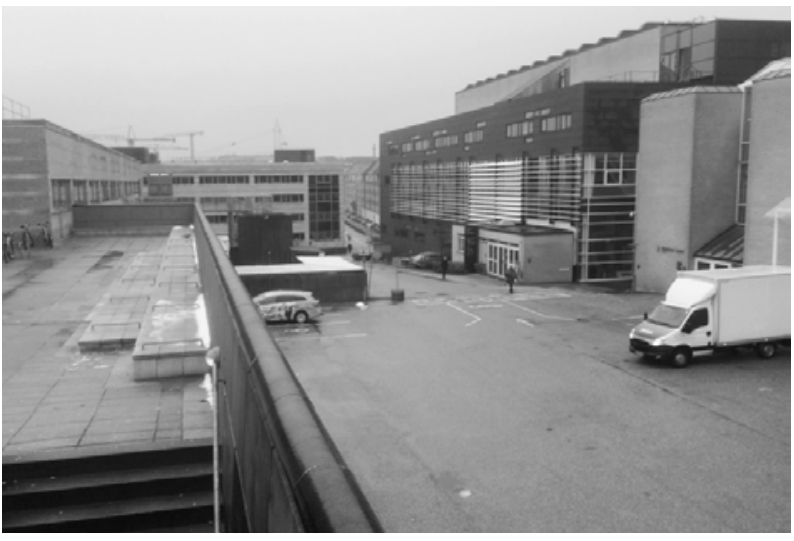

Fig. 15. The service area between the Musikhus and the Scandinavian Conference Centre, Aarhus. This is a large and uninviting expanse in the middle of the city

corner and having a setback, to accommodate turning vehicles, can quickly create a junction which feels out of proportion to the heights of the surrounding structures (Scottish Government 2010).

What emerges from this consideration of corners is the way in which some solutions avoid exposing gable walls and back walls so that the main streets are faced only or predominantly by primary facades (Trancik 1986: 34). Access to the rear for deliveries or services can be made possible through archways or small gaps in the facade. The contemporary preference for free-standing buildings avoids some of the compromises needed when buildings are constructed with party walls. It also accommodates the greater scale of buildings required. However, the large, free-standing building leaves three or more extra walls to be decorated to some level of acceptability (Trancik 1986: 34). It also means that three minor and non-communicative walls are exposed. Roads whose length are taken up by side walls or rear walls end up turning into the functional equivalent of laneways or service roads (see Fig. 15 above).

\section{Solutions}

The question arises as to what can be done to design better street junctions. At one level, the question relates to regulations. The building regulations which have evolved over the last 75 years need to be revised. Motor vehicles are now not seen as the most important mode of transport. Planning guides tend towards the quantitative in which terms it is hard to express or articulate this issue.

At another level, architects and their clients must consider engagement with the limitations imposed by building conventionally-realised corners. It is a paradox of contemporary design that so much is made of the efforts taken to resolve the small-scale elements of craftsmanship yet there is not much concern evident for the way buildings themselves, fit together as street blocks. There are problems arising from conforming to the topology of the block with its shared party walls. It is a problem of degree but not of kind. There are numerous problems associated with all design solutions, not least high rise residential construction (see Gifford 2007 , for example) and low-rise sprawl. It is not the laws of physics nor the "Zeitgeist" that determine the form of the urban environment. It is a matter of policy and culture among practitioners.

Concerning the scope for implementing such a design choice, two possibilities exist. The obvious one is that construction of new areas might be conceived in terms of conjoined facades and fully integrated corner designs, as per Rob Krier's design for Kirschsteigfeld in Potsdam, Germany. More unconventionally there is also the possibility of creating new corners by infill construction. This is relevant in Scandinavia where post-war urban growth has favoured blocks of apartments arranged on sites according to the needs of light in-fall (see Fig. 10 above). Whilst much publicity goes to new, ever taller, "iconic" high-rise buildings, there is tremendous potential to change and improve the character of suburban neighbourhoods by connecting free-standing, parallel blocks of apartments. From a design point of view, the results are likely to be aesthetically interesting since they would offer a chance to add material, textural and volumetric variation to what can be rather uniform and characterless areas. Further, infill development of this type must be considered lowhanging fruit when it comes to densification of older suburbs. The alternatives of further city expansion or increasing density in the city centre by allowing taller buildings are both problematic in themselves.

\section{Discussion}

Aesthetically, the corner of streets matters as much as the fitting together of the parts of a piece of furniture or a consumer product. It is inconsistent that designers focus on the importance of the form of joins in automobiles, consumer goods generally and the cut and stitching of clothing but not joins in the city fabric. Among the many possible causes of this is that the focus has been on the wrong level of organisation, the individual building, when the design object is the built environment taken as a unified whole.

Arising from this consideration of the corner, the topology and hierarchy of facade, gable and rear-wall come into focus. Deriving from this observation one is then in a position to articulate what might be so unsatisfactory about some contemporary buildings or newer additions made to the classical urban fabric. In the first instance, it is not a problem of architectural style 
if we can define style as that aspect of a building that is non-functional or discretionary. The problem resides at a level higher, in the structure of the urban fabric. With private interests trumping public ones, the freestanding building is permitted to disrupt the pre-existing urban fabric. In economic terms, the free-standing unit externalises the costs inherent in the compromises required by the dense urban fabric of block, street, corners and facades. The free-standing building might itself be measurably better but, in qualitative terms, its relation to the city fabric is worse. We even have a visual theory to explain this: Gestalt theory which is about seeing the whole. The architecture of the freestanding building can be criticised for not integrating into a harmonious whole. The disrupted streetscapes of post-war cities and de-ruralised areas in suburbia and between towns do not conform to the same principles a good individual building conforms to. This is a paradox of architecture, that the rules applied at one scale (the building) are not applied at a larger scale (the street and city).

The consideration of the classical street corner and what made it possible leads onward to the nature of scale in modern buildings. The diagram below (Fig. 16, below) shows three simple ways of scale increase. There are hybrids, of course, which are not shown. Diagrams 1-3 in Figure 16 represent the first three steps of increasing building size in five directions.

The historic city block can be considered in a new way in the light of this growth problem. Diagram 4 in Figure 16 shows a non-parametric conception of building growth. It essentially takes the organic growth pattern of a street block and applies it to one single building. The use of corner arrangements brings to light a solution for large volumes of building. That solution is that when a volume of building reaches a certain size, there must be a discontinuity in the growth. In conventional architecture this phase change is the point the designer considers deploying light wells and atria or subdividing the required volume into smaller segments to create two or more conjoined volumes. In the organic growth of the pre-Modern period the corner is where the street block has reached a maximum length and further volume is accommodated by building at or near right angles. This process continues until the enclosed area of the plot reaches something approximating the size of street block we find comfortable. Behind this very roughly sketched out idea is
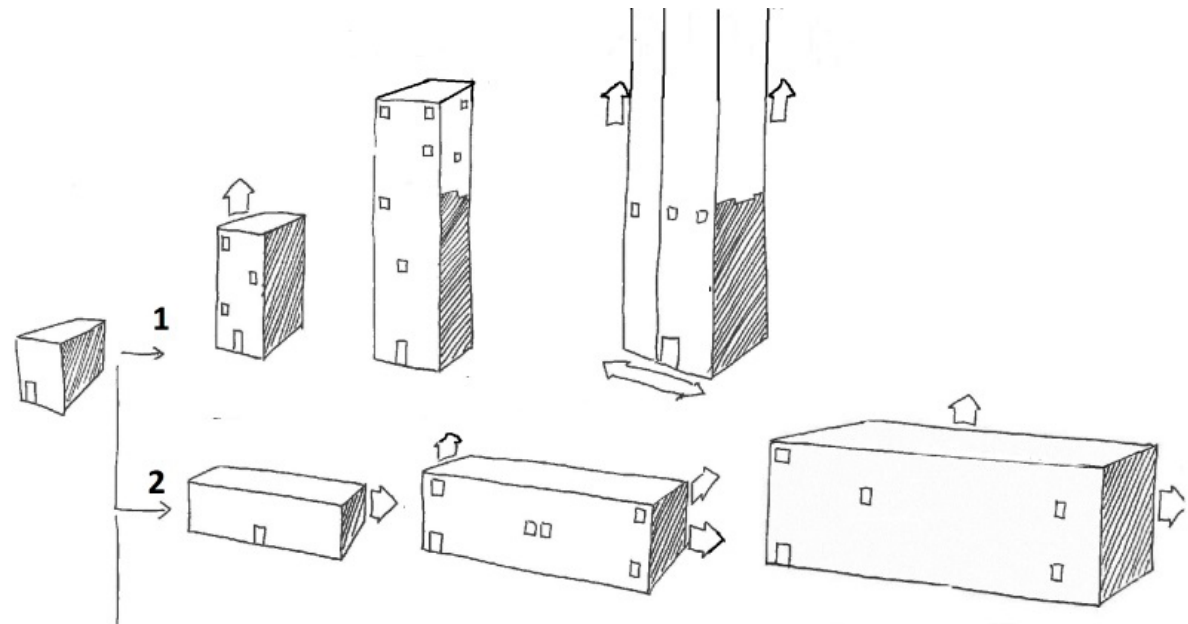

3
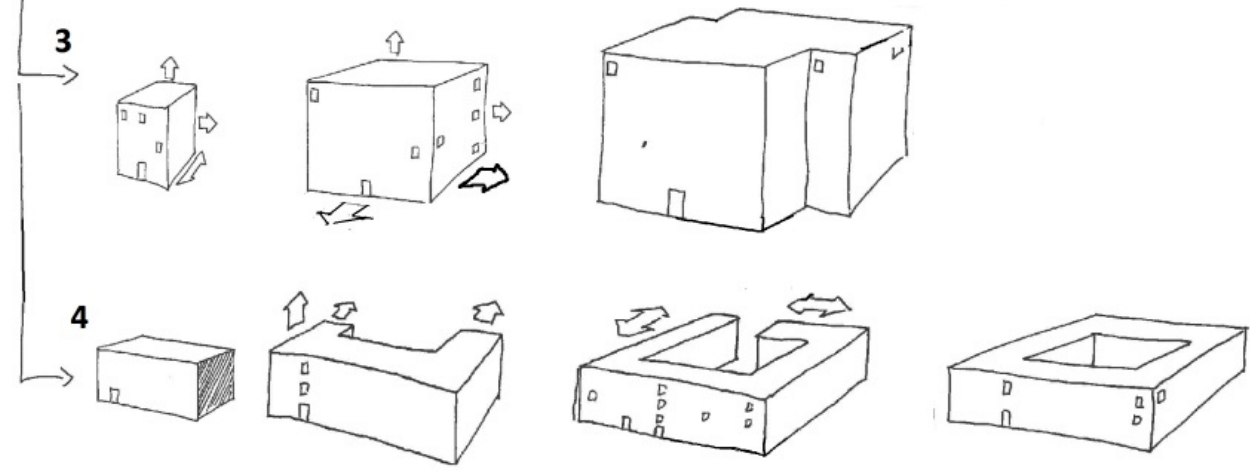

Fig. 16. How buildings can grow: (1) height (2) width (3) height width and depth, (4) Annular growth with direction changes at critical dimensions 
a possibility for further work based on a quantitative analysis of block lengths/widths, building heights and building depths. There is enormous room for variation within this conception, as much as within the range of accepted parameters defining garments, furniture and automobiles. Thus considered, the increased scale of modern buildings can be accommodated in ways that avoid an exposed rear or gable wall. Instead it opens up for exploring a format which can bring to urban areas an important characteristic lost with free-standing buildings of types 1-3 that disregard road alignments and the sheltering quality of moderate enclosure.

Finally, consideration of the resolved street corner building leads onward to the disappointing effect of car-based town planning and the over-prioritisation of purely quantitative parameters. This much we seem to be aware of. However, the lack of attention to matters such as the buildings' relations to each other is in part at the heart of what makes new urban areas so unsatisfying. Quantitatively, a new urban area can be as densely occupied as a classical city centre. That doesn't mean it will feel or function in the same way. Bowie's (2003) reference to "all the corners of the buildings" was probably deployed as an economical way to evoke precisely that kind of urban area in which the corners are matters of architectural interest, the classical or premodern city core. Corner buildings help define the space many think of a quintessentially urban and urbane.

\section{Conclusion}

Geuze (2006: 86) observes that the recipe for the street has been lost. It seems more like the recipe is being ignored. There has been much written about street proportions, facades, planting and layout. It is architects, developers and planners who are declining to use that recipe. Even where planners do try to encourage higher densities and more street-like arrangements of buildings, there is often something missing and the resultant streetscapes still seem incoherent or dis-integrated. The figure-ground relationship is unsatisfactory. Designing streets with conjoined corner buildings can help towards designing comprehensible public spaces. This might be unwelcome news to some architects who consider their activity a form of art and so reject prescription. However, in the same way that interface design, for example, operates within certain parameters (without being a matter of controversy) so some aspects of street design are probably also similarly constrained.

At the outset, it may seem that this article has a very prescriptive view of what "good" urban design is. This is not something I would deny. The important point is that those who seek to reject claims as to what constitutes "good" urban design also have an idea of what "good" urban design is. This other conception is equally prescriptive but is often hidden behind the terminology of necessity (planning codes, market preferences, for example) as if such "necessities" are not the result of negotiation and trade-off. Every school of design thought is, in its own way, prescriptive. Even preferring the outcome of random processes unrelated to architecture (e.g. favouring free market solutions) is to prescribe an acceptable or "good" outcome.

\section{References}

Arnheim, R. 1977. The dynamics of architectural form. Berkeley: University of California Press.

Bowie, D. 2003. New killer star. New York: Columbia Records.

Cuthbert, A. R. 2003. Designing cities: critical readings in urban design. Oxford: Blackwell.

Düwel, J.; Gutschow, N. (Eds.) 2013. A blessing in disguise: war and town planning in Europe. Berlin: Dom.

Ford, L. R. 2000. Spaces between buildings. Baltimore: Johns Hopkins University Press.

Gans, H. 1968 People and plans. New York: Basis Books.

Geuze, A. 2006.The street, in M. Moor, J. Rowland (Eds.). Urban design futures. Oxford: Routledge.

Gifford, R. 2007. The consequences of living in high-rise buildings. Architectural Science Review, Vol. 50. https://doi.org/10.3763/asre.2007.5002

Hayek, F. A. 1974. Studies in philosophy and economics. New York: Touchstone.

Holsten J. 1999. The modernist city and the death of the street, in S. M. Low (Ed.). Theorising the city. New Brunswick: Rutgers University Press.

Jacobs, A. 1993. Great streets. Cambridge. MA: MIT Press

Krier, L. 1994. The architecture of community. Washington DC: Island Press.

Krier, R. 1979. Urban space. London: Academy Editions.

Landry, C. 2006. The art of city making. New York: Earthscan.

Lynch, K. 1960. The image of the city. Cambridge, MA: MIT Press.

Lynch, K. 1984. Good city form. Cambridge, Mass: MIT Press.

Madanipour, A. 1996. Design of urban space. An inquiry into socio-spatial process. New York: Wiley.

Marshall, S. 2005. Streets and patterns. London: Spon Press

Michl, J. 1995. Form follows what?, Magazine of the Faculty of Architecture and Planning 10.

Moughtin, C.; Oc, T.; Tiesdell, C. 1992. Urban design: street and square. Oxford: Butterworth.

Moughtin, C.; Oc, T.; and Tiesdell, S. 1995. Urban design: ornament and decoration. Oxford: Butterworth.

Mumford, E. 2009. Defining urban design: CIAM architects and the formation of a discipline. New Haven: Yale University Press.

Neal, P. 2003. Urban villages and the making of communities. London: Spon Press. https://doi.org/10.4324/9780203402771

Norman, D. 2002. The design of everyday things. New York: Basic Books. 
Pye, D. 1978. The nature and aesthetics of design. Herbert Press: London.

Rossi, A. 1982. The architecture of the city. Cambridge, Massachusetts: MIT.

Shannon, C. F. 1949. Communication in the presence of noise, Proceedings Of The IRE 37(1): 10-21 https://doi.org/10.1109/jrproc.1949.232969

Scruton, R. 1994. The classical Vernacular. Manchester: Carcanet Press.

Scottish Government. 2010. Designing Streets: A Policy Statement for Scotland [online], [cited 1 December 2014]. Available from Internet:http://www.scotland.gov.uk/ Publications/2010/03/22120652/6

Southworth, M.; Ben-Joseph, E. 1997. Streets and the shaping of towns and cities. New York: McGraw Hill.

Steadman, P. 2014. Building types and forms. KibworthBeauchamp: Matador.

Stephan, R. (Ed.) 1988. Erich Mendelsohn. NY: Monacelli Press.

Syring, E.; Kirschemann, J. C. 2004. Hans Scharoun - outsider of Modernism. Taschen, Koeln.

Thiis-Evensen, T. 1987. Archetype in architecture. London: Norwegian University Press.
Trancik, R. 1986. Finding lost space. New York: Van Nostrand.

Weber, R. 1995. On the aesthetics of architecture. Aldershot: Avebury Press.

Vollmer, G. 1993. Wozu Pseudowissenschaft gut sind [What pseudosciences are good for], in Wissenschaftstheorie in Einsatz [Philosophy of Science in Action.] Stuttgart: Hirzel Verlag.

Willie Miller Architects. 2014. Tornagrain and Scottish Urbanism [online], [cited 7 February 2014]. Available from Internet: http://www.williemiller.co.uk/tornagrain-andscottish-urbanism.htm

Zevi, B. 1978. The modern language of architecture. Seattle/ London: University of Washington Press.

\section{RICHARD HERRIOTT}

is Assistant Professor of industrial design at the Design School in Kolding, Denmark. He holds a PhD awarded by the Aarhus School of Architecture. He researches aesthetics, user-centred design, design process and welfare design. 